\title{
Editorial - Rural Migrants: On the Fringe of the City, a Bridge to the Countryside
}

\section{Sylvie Démurger}

\section{OpenEdition}

\section{Journals}

Édition électronique

URL : http://journals.openedition.org/chinaperspectives/5331

DOI : 10.4000/chinaperspectives.5331

ISSN : 1996-4617

Éditeur

Centre d'étude français sur la Chine contemporaine

Édition imprimée

Date de publication : 15 décembre 2010

ISSN : 2070-3449

\section{Référence électronique}

Sylvie Démurger, «Editorial - Rural Migrants: On the Fringe of the City, a Bridge to the Countryside », China Perspectives [En ligne], 2010/4 | 2010, mis en ligne le 15 décembre 2010, consulté le 24 septembre 2020. URL : http://journals.openedition.org/chinaperspectives/5331 ; DOI : https://doi.org/ 10.4000/chinaperspectives.5331 


\section{Editorial}

\section{SYLVIE DÉMURGER}

$\mathrm{D}$ espite a rate of urbanisation reaching 48 percent in 2010, China's level of urbanisation lags relative to countries at a comparable level of development. ${ }^{(1)}$ During the country's economic transformation, urbanisation has been highly regulated through the dual urban-rural resident system of the hukou, a distinctive feature of China that imposes strong institutional barriers to migration. Unlike many developing countries that experienced a rapid urbanisation process, China avoided many problems associated with the rapid development of mega-cities, including slums, urban poverty, criminality, and social unrest. The other side of the coin, however, is that such regulation imposed a high cost on rural migrants, who contributed to urbanisation while remaining marginalised in cities.

The bulk of China's urbanisation process, which has been accelerating since 2000, consists of a massive rural labour exodus. The latest official figures released in March 2010 by the National Bureau of Statistics estimate the total number of rural migrant workers at 229.8 million as of the end of 2009. (2) Out of this total figure, 145.3 million (i.e., 63 percent) are working outside their hometowns (for a period over six months), and the remaining 84.5 million are working in their hometowns.

Although their contribution to the country's economic growth and industrialisation is largely recognised, rural migrants are denied the status of urban dwellers. Their precarious situation makes them highly vulnerable, as the recent economic turmoil of 2008-09 has proven: because they lack both formal employment contracts and urban benefits, migrant workers suffered the greatest exposure to the shock of the financial crisis. In the meantime, they are also becoming a social force to be reckoned with. With the number of migrants representing about 17 percent of China's 1.3 billion people, internal migration poses an unprecedented and complicated challenge to the country's development process. As China's urbanisation is expected to continue, China's urban population may increase by 350 million in 20 years, primarily from rural-to-urban migration flows. Moreover, new challenges are being brought about by the "new generation of migrants," a term coined in the 2010 Central Document No.l to refer to young migrants born in the 1980s and 1990s, more urbanised, more aware of their own rights, less obedient, and preferring to settle down in cities rather than returning to rural areas. Hence, maintaining a sustainable migration and urbanisation process will present the government with extremely challenging policy choices in the management of the expanding migrant population, the provision of adequate urban infrastructure and public services, and the securing of public safety and social stability. And indeed, the importance of such questions has been acknowledged in the new national Five-Year Plan for 2010-2015, which "calls for the government not only to encourage domestic migration between regions, but also to improve the conditions for rural people to move and settle in the cities." ${ }^{(3)}$

This issue of China Perspectives intends to shed new light on some dimensions of the complex phenomenon of internal migration in China. The collection of papers tackles the question through two complementary angles. First, they examine the status, the difficulties, and the achievements of rural migrants in their urban life. Second, they analyse to what extent rural migrants contribute to the development of their source communities. The first approach documents a variety of dimensions that illustrate the degree to which rural migrants are marginalised citizens in cities, while the second throws light on how these rural migrants can connect cities with the countryside, and urban workers with peasants.

All the papers included in this collection share a common feature: they are based on first-hand data collected between 2006 and 2008 in various regions of China. In view of the ever-shifting situation of rural migrants, exploiting recent individual or household surveys is a key to understanding the phenomenon and its implications for both urban and rural development. As urbanisation reaches new heights, such issues are becoming increasingly prominent and strategically important in promoting a sustainable process.

Using data on rural migrants in 16 cities selected from nine provinces in 2007, Li Shi's opening paper provides an overview of the situation of rural migrants in urban China and highlights the progress made as well as the challenges facing this population. It also reviews a number of recent initiatives launched to improve the migrant workers' situation in cities.

1. J. Vernon Henderson, "Urbanization in China: Policy issues and options," unpublished manuscript, Brown University, 2009, http://www.econ.brown.edu/faculty/henderson/.

2. National Bureau of Statistics, Report on the rural migrant workers monitoring survey, Rural Department of NBS, 2010, http://www.stats.gov.cn/tjfx/fxbg/t20100319_40262 8281.htm.

3. Gang Fan, "China's Great Migration," Project Syndicate, 2010, http://www.project-syndicate.org/ commentary/fan19/English. 
The next three papers deal with more specific dimensions of rural migrants' life in the cities and document three major aspects: income and poverty, access to health care, and occupational choices in cities. The major obstacles to the integration of the migrant population into urban society come from a variety of administrative, economic, and social sources of discrimination that are mostly related to the two-tiered hukou household registration system. Lacking the same status as city dwellers, migrant workers face major inequalities in the cities. They are denied equal access to public services and to job opportunities; they face poor, unfair, and unsafe working conditions; and they work primarily in the informal sector.

The vulnerable status of migrant workers compared to their urban counterparts is reviewed in this special issue through the angles of work opportunities, employment and living conditions, and access to social public welfare. First, using data on rural migrants collected in four large cities (Beijing, Shanghai, Tianjin, and Guangzhou) in 2008, Guo Fei and Cheng Zhiming analyse the employment and income situation of three different groups of urban workers: urban dwellers, urban migrants, and rural migrants. They find clear disparities between these components of the labour force in terms of the means for obtaining jobs and the types of employment. Their results also indicate that urban poverty and inequality are severe and that rural migrants are a major segment in the urban poor class. In a complementary approach, Carine Milcent studies the determinants of healthcare access for rural migrants in five cities (Chongqing, Dalian, Shanghai, Shenzhen, and Wuhan) surveyed in 2006. She highlights two exclusion factors for rural migrants, one related to their low income, and the other related to their lack of integration in the city. A key finding of this study is that social networks play a decisive role in providing greater access to healthcare for migrant workers. Third, Gilles Guiheux and Pierre-Paul Zalio shed light on the working conditions and opportunities of moderately skilled young service migrant workers in the prosperous metropolis of Shanghai. Using qualitative data from fieldwork conducted in Shanghai in 2007 and 2008, they analyse the individual careers of real estate brokers and show how migrants involved in new urban service professions cope with their unstable position in the city.

The last two papers of the collection offer a complementary view by focusing on the economic impact of migration in their communities of origin. They analyse how remittances affect the welfare of the left behind and how return migrants may influence rural development. A noteworthy and mean- ingful feature of the two papers is that both use data from Anhui Province, a pioneering sending area with large-scale migration since the early 1980s, and a pioneering receiving area with the return of a large number of migrants.

Using data on rural households collected in Jiangsu and Anhui provinces in 2006, Wang Meiyan analyses the impact of remittances on rural poverty reduction on the one hand, and on rural households' living expenditure on the other hand. She finds that remittances sent by migrants to their rural families play a significant role in reducing the rural poverty rate, and that the impact is particularly important in the poorer province of Anhui. Nevertheless, regarding living expenditure, she shows that rural households use remittances mainly for current consumption rather than for investment in health or housing, and again that this is particularly the case in the poorer province, Anhui. Finally, Xu Hui analyses the occupational change of return migrants in a county of Anhui Province surveyed in late 2008. She shows that return migrants experience occupational upward mobility as compared to their pre-migration occupation and that they are more likely to enter self-employment than nonmigrants. These findings highlight the beneficial role that rural migrants play upon their return by setting up businesses that require higher set-up funds, thereby increasing local employment opportunities in rural areas.

The unprecedented rural-urban migration phenomenon that China is witnessing is complex and multi-dimensional. While providing a comprehensive overview of the phenomenon is far beyond the scope of this special issue, the collection of articles offered here tackles some important aspects of how rural migrants in China are both on the fringe of the city and a bridge to the countryside. $\bullet$ 